Joanna Rokita-Jaśkow

https://doi.org/10.26881/pwe.2021.52.11

ORCID: 0000-0002-6272-9548

Uniwersytet Pedagogiczny im. Komisji Edukacji Narodowej w Krakowie joanna.rokita-jaskow@up.krakow.pl

\title{
Werona Król-Gierat
}

ORCID: 0000-0001-6522-2550

Uniwersytet Pedagogiczny im. Komisji Edukacji Narodowej w Krakowie werona.krol-gierat@up.krakow.pl

\section{Preparing teachers of Early Childhood Education to teach a foreign language: the PEPELINO portfolio in practice}

\section{Summary}

Teaching a foreign language at pre-primary level has been officially introduced in Poland in 2015 as a follow-up to European policy guidelines (European Commission 2011b). Teachers are agents of any language policy as it is them who have to warrant its implementation through pedagogical practice. While most of the studies conducted on policy implementation focus on teacher beliefs and multilingual practices (e.g., Haukås 2016; Lundberg 2019), the following paper concentrates on implementing European language policy guidelines in respect of early foreign language education and pluralistic approaches. It describes a quantitative study of early education in-service teachers who attended a 3 -semester preparation course for language teaching. The data analysis revealed that 'supporting the linguistic development of children with other first languages than Polish' gained the least support among the respondents, despite a significant course module devoted to this issue. Therefore, the conclusion can be drawn that the teachers will be able to raise interest in language learning by very young learners, by drawing on their experience as Early Childhood Educators, yet it will be difficult to foster plurilingualism and attitudes of intercultural interest by teachers who often lack intercultural experience and plurilingual awareness themselves.

Keywords: language teaching, very young learners, language policy, PEPELINO portfolio

Słowa kluczowe: nauczanie języków obcych, dzieci, polityka językowa, portfolio PEPELINO

\section{Introduction}

Teaching foreign languages to young learners has become a global phenomenon (Murphy, Evangelou (eds.) 2016; Enever 2018). Its origins can be traced back both to parental aspirations, as well as supportive language policy whose aim is to secure young children with best educational credentials through early and continuous exposure to foreign languages. 
Naturally, this demand causes a need for highly educated teachers who should understand both the psycho-pedagogical underpinnings of teaching children, as well as didactics of early foreign language teaching.

Over the course of the last decade, the European language policy (henceforth: ELP) which acts as a model to many other countries and their educational policies (Enever 2018), has focused on lowering the age of starting instruction further to the pre-primary level by issuing the language policy guidebook titled Language learning at pre-primary level: making it efficient and sustainable (European Commission 2011b). The natural follow-up to issuing the document has been investments into pre-primary language teacher education. One such measure has been the project realised by the European Centre of Modern Languages in Graz which resulted in producing the European Portfolio for Pre-Primary Educators of Foreign Languages (PEPELINO) (Goullier et al. 2015). The document, similarly, to previous types of portfolios (e.g., EPOSTL, the European Portfolio for Student-Teachers of Languages) (Newby et al. 2007) is supposed to assist trainee teachers in developing reflective practice in the occupation while promoting European values of intercultural interest and mutual understanding. At this point it has to be emphasised that Poland was among pioneer countries which introduced the policy of very early teaching of foreign languages i.e., to pre-primary children, already in 2015 (Rokita-Jaśkow, Pamuła-Behrens 2019).

This article aims to present the results of a study carried out among pre-primary educators in Poland, who underwent training in early foreign language didactics and used the PEPELINO Portfolio (Goullier et al. 2015) as a part of their teacher training.

\section{European language policy (ELP) in pre-primary education}

The emphasis on early teaching of languages in the European policy goes back to the 1990s, where the need to speak many languages or individual plurilingualism (Byram 1997; Council of Europe 2001) was voiced as a prerequisite to achieving social cohesion and mutual understanding among citizens of the European Union (European Commission White Paper: Teaching and Learning-Towards the Learning Society 1995: 67). Plurilingualism is defined in Common European Framework of Reference for Languages as 'the ability to use languages for the purposes of communication and to take part in intercultural interaction, where a person, viewed as a social agent, has proficiency of varying degrees, in several languages, and experience of several cultures' (Council of Europe 2001). Therefore, it was recognised as an important asset of the human capital, which can be utilised in building 'the knowledge society' (European Council 2000). It is the belief of the authors of this paper that individual plurilingualism may be particularly strived for in societies which have fewer opportunities for implicit learning of languages by living and communicating with multilingual members of their societies, as it is the case in Poland.

In 2011 the European Commission (2011a) published a report analyzing the current state of teaching foreign languages to the very young, which in response to parental de- 
mand, already took place in many countries, mainly on a fee-paying basis. The analysis was subsequently followed by the policy implementation guidebook titled 'Language learning at pre-primary school level: making it efficient and sustainable '(European Commission 2011b) and was directed at EU member state countries for consideration. The guidebook specifies the benefits of very early foreign language learning, which are limited to general cognitive and affective development, and not to achieving native-like mastery in a language. Openness to new languages and cultures was highlighted as the most prominent affective benefit of such an early exposure to languages. What is more, it is highlighted in the document that these goals can only be met if proactive policy supporting pre-primary foreign language teaching is implemented, characterized by equity in access to free education, quality in teaching instruction, consistency of curricula in various contexts and continuity from pre-primary level to the next.

Since Poland joined the EU in 2004, it soon started to eagerly implement guidelines of the European language policy via educational reforms such as the one in 2009, which levelled the onset of obligatory foreign language instruction with the onset of schooling at the age of 7 (cf. Rokita-Jaśkow, Pamuła-Behrens 2019). Additionally, in the same reform, continuity of foreign language learning was guaranteed between subsequent levels of education, i.e., from primary to lower-secondary and from lower-secondary to upper-secondary, so that each learner had to take a school-leaving exam in a foreign language at least at the B2 level according to CEFR scale. What is more, two languages were available for learning in the public education system, usually English being chosen as the first foreign language.

In a similar vein, soon after the policy handbook (European Commission 2011b) for teaching foreign languages at pre-primary level was issued, the Polish government issued a bill lowering the onset of obligatory schooling to the age of 6;0 (formerly 7;0) (Ministry of Polish Education 2014) and introducing obligatory foreign language instruction to the pre-primary level, which was to be implemented gradually year by year, first to 5-yearolds in 2015, and finally to 3-year-olds in 2017.

The goals of early FL teaching were specified in point 11 of the Polish Core Curriculum for Early Childhood Education (Ministry of Polish Education 2014, 2017), and were as follows:

Preparing children for using a modern foreign language by arousing their language awareness and intercultural sensitivity as well as building positive motivation for FLL at further stages of education, and in the case of children with intellectual disability - developing awareness of the existence of linguistic and cultural diversity.

(Core Curriculum for Early Childhood Education, App. to the regulation of Ministry of Polish Education, 30 May 2014, point 895 (Authors' translation))

What follows from both the Policy Handbook (European Commission 2011b) and the Polish curriculum for pre-primary education is their strong emphasis on foreign language competence as a key to mutual understanding. It is believed language learning broadens 
one's mind and enables insight into other communities of language speakers. Consequently, it teaches curiosity and tolerance towards unknown cultures and people.

\section{Teachers of very young learners as agents of ELP - research perspectives}

In ELP documents (e.g., European Commission 2011a) it is assumed that the very experience of language learning can lead to a change in attitude towards others and of general life orientations. It is thus the role of teachers to transfer these policy assumptions into practice. As Kirsch writes, teacher agency is crucial in implementing any language policy guidelines as "teachers and students, among others, appropriate, interpret and negotiate policies when they implement them in their local context" (2018: 3). Åsta Haukås (2016: 3 ) has additionally outlined criteria which teachers should fulfill if they wish to follow a multilingual pedagogical approach. They are:

- They should be multilingual themselves and serve as models for their learners.

- They should have a highly developed cross-linguistic and metalinguistic awareness.

- They should be familiar with research on multilingualism.

- They should know how to foster learners' multilingualism.

- They should be sensitive to learners' individual cognitive and affective differences.

- They should be willing to collaborate with other (language) teachers to enhance learners' multilingualism (Haukås 2016: 3).

Different societies may have different historical pasts and thus different needs, goals or aspirations. These contextual determinants shape individual countries' language policies and in unison impact the language teachers' beliefs.

Most studies that have been conducted in the last two decades on the beliefs of language teachers and policy implementation were conducted in reference to multilingualism and in multilingual societies (De Angelis 2011; Haukås 2016; Kirsch 2018; Lundberg 2019). Only a handful looked at the link between teacher beliefs and early language learning in school settings (Rokita-Jaśkow 2016; Fojkar, Skubic 2017). In the case of the latter, they aimed to dispel the myths about the goals of early foreign instruction held by many teachers (Rokita-Jaśkow 2016; Fojkar, Skubic 2017) while in the case of the former they sought the link between teacher beliefs and agency in implementing multilingual pedagogies. The study of Bustos Flores (2001) provides important evidence for the link between teacher beliefs and their practices, as the latter influence the former. In her study she found that in bilingual education programmes these were bilingual teachers who were better equipped to help their bilingual students than monolingual teachers, particularly if they had 'a conscious, shared ethnic identity', as 'they are likely to intuitively recognize the needs of their bilingual learners' (Flores 2001: 292). She additionally emphasised that teachers need to systematically re-evaluate their beliefs by critical self-reflection. By the 
same token Haukås (2016: 12) observed in the Norwegian school context that multilingual teachers believed "their own multilingualism had been beneficial to their language learning and were more aware of how to use their previous knowledge in further language learning" than their students, and therefore they were able to provide help to their learners learning third languages (L3). In the multilingual class they frequently drew on the knowledge of languages common to all children, i.e., English and Norwegian, referring to the similarities between them. It is noteworthy that the author also mentions the European language portfolio as the major tool "developing learner's multilingual awareness" (Haukås 2016: 13).

Additionally, Laura Portolés and Otilia Martí (2018) observed a beneficial impact of teacher training on the change of pre-service teachers' beliefs towards multilingualism, showing that they are modifiable. At the end of instruction not only did they show a change in attitude towards perceiving multilingualism as having cognitive advantages, but they also observed that the ideal teacher of languages does not have to be a native speaker.

What comes from these studies is the observation that if teachers are to be efficient agents of language policy, in this case promote plurilingualism and intercultural interest through early language learning, they must have a long-standing experience of language learning and use in multilingual contexts. Only on this condition can they treat a foreign language as a tool of communication and shaping attitudes of openness and curiosity towards the other. However, there is a hope for change of attitudes also through pre- and in-service training, as was shown by Portolés and Martí (2018). To support this point, Agnieszka Otwinowska (2017) found that teachers who benefit from their previous experience as multilingual language learners and are trained in accordance to multilingual pedagogies become more successful in their teaching practices, and thus teachers' plurilingual awareness, including metalinguistic, psycholinguistic and sociolinguistic awareness, should be raised.

\section{The European language portfolio for pre-primary educators}

If teachers are to be agents of the European language education policy, they need to be equipped with competences to do so. Such is the role of PEPELINO (Goullier et al. 2015), which was developed at the European Centre for Modern Languages (ECML). It is a tool which can support teachers throughout their initial and in-service professional learning. It is designed to help pre-primary educators in self-evaluation. The name PEPELINO was derived from the French acronym for the publication: $\mathrm{P}$-Portfolio, E-Europeen, $\mathrm{P}$ - pre, $\mathrm{E}$ - elementaire, L-langues, $\mathrm{IN}$ - interculturel, $\mathrm{O}$.

PEPELINO breaks down the professional skills which young learner (YL) teachers should perform when catering for children's linguistic and cultural development, into four domains and eight fields of competence, with each domain being divided into two fields of competence: 
- Adopting appropriate behaviour.

- Analysing and adapting how to talk to children.

- Responding positively to linguistic and cultural diversity.

- Creating a favourable learning environment for children.

- Taking account of the way in which young children acquire languages.

- Organising activities on the theme of languages and diversity.

- Observing and supporting each child's development.

- Taking children's individual needs into account.

- Supporting the linguistic development of children with other first languages.

- Cooperation.

- Cooperating with the children's families.

- Working as a team (Goullier et al. 2015: 8).

Furthermore, each of these fields of competences accompanied by five descriptors (detailed statements), being a combination of appropriate knowledge, skills and attitudes. It must be highlighted that the portfolio has been prepared in line with the most up-to-date knowledge on the possible achievements of very young learners and early years pedagogy. Thus, it is not only a language policy implementation instrument but a training and selfreflection tool.

\section{The research design}

\section{The rationale and purpose of the study}

As stated previously, soon after the publication of the language policy guidebook for preprimary education (European Commission 2011b), Poland decided to follow its recommendations and gradually implement early foreign language instruction from 1 September 2015, first to 5-year-olds, then to 4-year-olds and finally to 3-year-olds in 2017. Naturally, this legislation called for the need of highly qualified foreign language teachers of young learners, who would be knowledgeable both in early years pedagogy and in a foreign language (at least at the B2 level). A few options of gaining additional qualifications were open, one of which were postgraduate studies for Early Childhood Educators in foreign language skills and pedagogy. This study was conducted on the basis of two premises. Firstly, that very early foreign language learning is an outcome of political measures, and the PEPELINO portfolio is a teacher education tool, helping to implement these measures. Secondly, it is assumed that teachers should be agents of the policy helping to implement its assumptions.

Consequently, the current study aimed to investigate to what extent the in-service preprimary teachers of English as a Foreign Language are prepared to implement language policy guidelines concerning very early foreign language instruction. It was also intended as a self-assessment of the development of these competences in the course of the postgraduate studies for pre-primary educators which lasted a year and a half. The participants 
were asked to indicate what skills they believed they had after the training. More precisely it was aimed to find answers to the following research questions:

- Q1: Can teachers be sufficiently prepared to implement the guidelines of the European Language Policy in respect of early language learning in a 3-semester postgraduate course?

- Q2: Which competences did the pre-primary educators develop the most and the least during the course of training?

- Q3: Which descriptors, reflecting current teacher beliefs, gained the strongest support within each category of the professional competences described in PEPELINO?

\section{Procedure and instrument}

During the postgraduate studies, the participants took part in many courses, ranging from those developing purely their language skills (Practical English, Phonetics), Second Language Acquisition theory, to those in TEYL (Teaching English to Young Learners) methodology, including practical workshops and practicum in a kindergarten. Additionally, elements of the PEPELINO (Goullier et al. 2015) have been systematically used as a training and reflective tool in the course of the 3 -semester study.

At the end of the studies teacher preparedness to implement language policy guidelines was investigated by means of a quantitative survey, which included the competency descriptors in the portfolio (Goulier et al. 2015: 104-107). To each of the statements the participants had to indicate their level of agreement. The participants were to decide to what extent they agree with a given statement on a 5-point Likert-type scale, in which 1 - meant 'Definitely No' and 5 denoted 'Definitely Yes'. The statements were translated into Polish, the participants' L1, to avoid misunderstanding. Additionally, at the end of the questionnaire the respondents were asked one open-ended question about any suggestions for modification of the course syllabus. The survey was distributed in class in a pen and paper form.

\section{Research participants}

The participants of the research project were in-service pre-primary educators who enrolled for postgraduate studies at the Pedagogical University of Cracow, Poland, in order to receive additional training in TEYL methodology, as well as, to develop their language skills to reach the B2 level. Obtaining such additional qualifications was required by the ministerial regulations (Ministry of Polish Education 2014). Altogether 74 female participants from the two editions of the course took part in the study. Within this number, 43 subjects (58\%) had no experience in TEYL, $24(32,5 \%)$ had been teaching English to YLs for a year or two, and only $7(9,5 \%)$ had been teaching the language for more than two years. The mean length of teaching experience was about 5 months. This shows that these were mainly young teachers who decided to participate in an additional training, and thus the results could be different with more experienced teachers of foreign language TLL. 


\section{Data analysis}

The following section presents the findings of the study. Table 1 shows the mean scores obtained by the participants at the end of the course for each of the key competences.

Table 1. Professional competences developed by the research participants

\begin{tabular}{|c|c|}
\hline \multicolumn{1}{|c|}{ Field of competence } & Mean score \\
\hline I. Talking to children in L2 & 4.29 \\
\hline II. Attitude to linguistic and cultural diversity & 4.21 \\
\hline III. Understanding how children learn & 4.44 \\
\hline IV. Organising lessons on the theme of languages and diversity & 4.16 \\
\hline V. Responding to children's individual possibilities and needs & 4.30 \\
\hline $\begin{array}{l}\text { VI. Supporting the linguistic development of children } \\
\text { with other first languages than Polish }\end{array}$ & $\mathbf{3 . 8 7}$ \\
\hline VII. Cooperation with parents & 4.40 \\
\hline VIII. Cooperation with colleagues & $\mathbf{4 . 5 4}$ \\
\hline
\end{tabular}

Source: Authors' own analysis.

The professional competence which has been developed the most by the pre-primary educators taking part in the training was the ability to cooperate with colleagues (Mean $=4.54$ ), which is a good predictor for the future since the effectiveness of teaching depends partly on how it links with the work of other professionals contributing to children's linguistic or cultural development. During the studies the pre-primary educators were provided with a lot of opportunities for teamwork during their training, especially during practical didactic workshops. Observing other teachers at work, sharing with them opinions on teaching practice, and devising and implementing joint projects were common ways of professional training and development. Consequently, exchange of ideas and experiences, observation and joint ventures prompted beneficial personal reflection as regards this descriptor.

By contrast, supporting the linguistic development of children with other first languages than Polish was the weakest point in the trainees' progress (Mean = 3.87). This may boil down to the fact that the teachers themselves have had little intercultural experience, having worked mainly with monolingual children, and therefore may oversee this goal in their teaching. Another explanation could be that this issue might have been underpresented in the training.

Each field of competence has been broken down into subsidiary descriptors, which related to knowledge, attitudes and skills. As regards the first field of competence (Tab. 2) talking to children in $\mathbf{L} \mathbf{2}$ - the pre-primary educators have gained the best skills in telling whether the language they are using is well adapted to the abilities and needs of children 
in this age group $(\mathrm{M}=4.51)$. This aspect is of utmost importance since the linguistic input that children are exposed to is the one from which they learn the foreign language at school. Therefore, the utterances directed towards young learners must be adapted to each child's capacity for understanding, and effectively foster each child's progress.

Table 2. Talking to children in L2

\begin{tabular}{|l|c|}
\hline \multicolumn{1}{|c|}{ I. Talking to children in L2 } & Mean score \\
\hline $\begin{array}{l}\text { 1.1. I can tell whether the language I am using is well adapted to the abilities } \\
\text { and needs of children in this age group }\end{array}$ & $\mathbf{4 . 5 1}$ \\
\hline $\begin{array}{l}\text { 1.2. I can react effectively when the children do not seem to understand } \\
\text { everything I am saying to them }\end{array}$ & 4.43 \\
\hline 1.3. I can make each child feel involved in the discussions & 4.18 \\
\hline $\begin{array}{l}\text { 1.4. I can encourage children to participate actively in discussions } \\
\text { 1.5. I can use the language(s) that I speak with the children for achieving } \\
\text { specific objectives in terms of their linguistic development }\end{array}$ & 4.05 \\
\hline
\end{tabular}

Source: Authors’ own analysis.

When it comes to the second field of competence (Tab. 3) - attitude to linguistic and cultural diversity - the teachers claim to respond positively when linguistic and cultural diversity is manifested in the way children express themselves or behave $(M=4.61)$. Although it is clear that diversity should be recognised and welcomed as a vehicle for all children's development, linguistic and cultural differences are still not often present in the Polish context. Therefore, the high score of the descriptor is a positive indicator, since teacher attitude to linguistic and cultural diversity can impact on young learners' outlook on welcoming learners of multicultural background in class as well raise interest in other languages and cultures.

Table 3. Attitude to linguistic and cultural diversity

\begin{tabular}{|l|c|}
\hline \multicolumn{1}{|c|}{ II. Attitude to linguistic and cultural diversity } & Mean score \\
\hline 2.1. I can convey to the children my interest in linguistic and cultural diversity & 4.08 \\
\hline $\begin{array}{l}\text { 2.2. I can respond positively when linguistic and cultural diversity is manifested } \\
\text { in the way children express themselves or behave }\end{array}$ & $\mathbf{4 . 6 1}$ \\
\hline $\begin{array}{l}\text { 2.3. I can treat certain children's plurilingualism and experience of different } \\
\text { cultures as a genuine resource for the group }\end{array}$ & 4.11 \\
\hline $\begin{array}{l}\text { 2.4. I can take action to ensure that children who speak other languages or come } \\
\text { from different cultures receive a positive welcome in the institution }\end{array}$ & 4.31 \\
\hline $\begin{array}{l}\text { 2.5. I can identify possible causes of misunderstanding due to differences } \\
\text { of cultural behaviour and act as a mediator between children and adults }\end{array}$ & 3.92 \\
\hline
\end{tabular}

Source: Authors' own analysis. 
It is also notable that in the third field of competence (Tab. 4) - understanding how children learn - the participants have learned to use the resources offered by information and communication technologies (ICT) to develop the children's language skills and cultural awareness $(\mathrm{M}=4.61)$. Undoubtedly, ICT tools offer additional possibilities for exploiting the playful dimension of language use and boost children's motivation to experiment and learn. Information technology can also be effectively incorporated into group management. During the postgraduate training, the educators were offered a course about the use of ICT with young learners, so they had the opportunity to get acquainted with and test diverse mobile applications, computer software, online tools, and resources for use with young and very young learners of English.

Table 4. Understanding how children learn

\begin{tabular}{|l|c|}
\hline \multicolumn{1}{|c|}{ III. Understanding how children learn } & Mean score \\
\hline $\begin{array}{l}\text { 3.1. I can organise the classroom space in a way that encourages the children } \\
\text { to join in with language-related activities and to interact with each other }\end{array}$ & 4.47 \\
\hline $\begin{array}{l}\text { 3.2. I can encourage the children to use non-verbal communication to support } \\
\text { oral expression }\end{array}$ & 4.53 \\
\hline $\begin{array}{l}\text { 3.3. I can make use of each activity to foster the children's linguistic } \\
\text { development }\end{array}$ & 4.22 \\
\hline $\begin{array}{l}\text { 3.4. I can take account of the emotional dimension in linguistic exchanges } \\
\text { with and between the children }\end{array}$ & 4.36 \\
\hline $\begin{array}{l}\text { 3.5. I can use the resources offered by information and communication } \\
\text { technologies to develop the children's language skills and cultural } \\
\text { awareness }\end{array}$ & $\mathbf{4 . 6 1}$ \\
\hline
\end{tabular}

Source: Authors' own analysis.

Referring to the fourth field of competence (Tab. 5) - organising lessons on the theme of languages and diversity, the research subjects assert that they have learned to draw maximum benefit from the moments when the children start to become aware of how the language works $(\mathrm{M}=4.32)$. The growth of a metalinguistic awareness, i.e., a gradual development of a set of multiple skills (Bialystok et al. 2014) that are related to the phonological, morphological, syntactic and lexical aspects of languages (Altman et al. 2018), is conducive to the acquisition of the first and foreign languages. 
Table 5. Organising lessons on the theme of languages and diversity

\begin{tabular}{|l|c|}
\hline \multicolumn{1}{|c|}{ IV. Organising lessons on the theme of languages and diversity } & Mean score \\
\hline $\begin{array}{l}\text { 4.1. I can draw on the presence of different languages and cultures } \\
\text { in the immediate environment }\end{array}$ & 4.20 \\
\hline $\begin{array}{l}\text { 4.2. I can guide the children in their encounters with different linguistic } \\
\text { or cultural behaviour and encourage them to talk about this subject }\end{array}$ & 4.15 \\
\hline $\begin{array}{l}\text { 4.3. I can draw maximum benefit from the moments when the children start } \\
\text { to become aware of the workings of the language }\end{array}$ & $\mathbf{4 . 3 2}$ \\
\hline $\begin{array}{l}\text { 4.4. I can give a communicative dimension to moments of reflection about } \\
\text { language }\end{array}$ & 4.07 \\
\hline 4.5. I can stimulate children's curiosity about written texts & 4.05 \\
\hline
\end{tabular}

Source: Authors' own analysis.

With regard to the fifth field of competence (Tab. 6) - responding to children's individual possibilities and needs - the pre-primary teachers claim that they have best learned to ensure that each child is given the opportunity to speak during lessons $(M=4.55)$. Children's oral output provides clues about their current language learning levels. At the same time young learners need to feel secure to express themselves at their own pace and be shown that they are listened to, that their contributions to the discussion are valued. Also, they should be encouraged to take risks in the use of language (Cregan 2019).

Table 6. Responding to children's individual possibilities and needs

\begin{tabular}{|l|c|}
\hline \multicolumn{1}{|c|}{ V. Responding to children's individual possibilities and needs } & Mean score \\
\hline $\begin{array}{l}\text { 5.1. I can identify each child's communication skills and language needs using } \\
\text { appropriate observation instruments }\end{array}$ & 4.33 \\
\hline 5.2. I can help each child progress at his/her own pace & 4.28 \\
\hline 5.3. I can ensure that each child is given the opportunity to speak during lessons & $\mathbf{4 . 5 5}$ \\
\hline 5.4. I can help develop each child's confidence in the use of the foreign language & 4.01 \\
\hline 5.5. I can adjust my teaching to children's difficulties and possibilities & 4.42 \\
\hline
\end{tabular}

Source: Authors' own analysis.

With reference to the sixth and the least developed field of competence (Tab. 7) - supporting the linguistic development of children with other first languages than Polish - the study participants affirm to have learned how to encourage exchanges between children with different levels of proficiency in the language being used $(M=4.11)$. It can be claimed that the pace of the development in L2 of children who at home use a language that is different from L1 of other peers must be understood and respected. 
Table 7. Supporting the linguistic development of children with other first languages than Polish

\begin{tabular}{|c|c|}
\hline \multicolumn{1}{|c|}{$\begin{array}{c}\text { VI. Supporting the linguistic development of children } \\
\text { with other first languages than Polish }\end{array}$} & Mean score \\
\hline $\begin{array}{l}\text { 6.1. I can take account of the specific situation of children with other first } \\
\text { languages than Polish in order to identify their individual abilities and needs }\end{array}$ & 3.74 \\
\hline $\begin{array}{l}\text { 6.2. I can take account in the support that I give these children of their particular } \\
\text { linguistic or cultural competences and knowledge }\end{array}$ & 3.73 \\
\hline $\begin{array}{l}\text { 6.3. I can help children to draw on their first language in order to make progress } \\
\text { in acquiring the language used for exchanges within the group }\end{array}$ & 3.73 \\
\hline $\begin{array}{l}\text { 6.4. I can encourage exchanges between children with different levels } \\
\text { of proficiency in the language being used }\end{array}$ & $\mathbf{4 . 1 1}$ \\
\hline $\begin{array}{l}\text { 6.5. I can react appropriately to verbal or non-verbal behaviour that may stem } \\
\text { from different cultural traditions }\end{array}$ & 4.05 \\
\hline
\end{tabular}

Source: Authors' own analysis.

As regards the seventh field of competence (Tab. 8) - cooperation with parents - the teachers $(\mathrm{M}=4.64)$ claim that they have learned how to exchange information with the children's parents about the progress of their offspring, which is crucial at this educational level. Young learners are not yet independent and autonomous enough so as to take full responsibility for their learning. The family environment plays a vital role in children's linguistic and cultural development. Therefore, there should be as much complementarity as possible between the educator's work and the action of the parents. Any observations made by the teacher concerning very young learners' communication behaviour should be shared and discussed. Meaningful exchanges with parents help them to understand the aims and methods of the language work being undertaken at school. Such exchanges may enable them to follow the work being done, to effectively support their children's linguistic development and to avoid having unrealistic expectations of the children's achievement (Goullier et al. 2015: 79-80).

Table 8. Cooperation with parents

\begin{tabular}{|l|c|}
\hline \multicolumn{1}{|c|}{ VII. Cooperation with parents } & Mean score \\
\hline $\begin{array}{l}\text { 7.1. I can see to it that all the people with responsibility for the child feel } \\
\text { welcome in the institution }\end{array}$ & 4.54 \\
\hline $\begin{array}{l}\text { 7.2. I can involve the parents in teaching projects that are directly related } \\
\text { to the children's linguistic and cultural development }\end{array}$ & 4.22 \\
\hline $\begin{array}{l}\text { 7.3. I can exchange with the children's parents about the activities that are } \\
\text { the most conducive to children's language acquisition }\end{array}$ & 4.43 \\
\hline $\begin{array}{l}\text { 7.4. I can exchange information with the children's parents about their progress } \\
\text { 7.5. I can encourage the incorporation of resources existing within the families } \\
\text { into the organisation of activities with the children }\end{array}$ & $\mathbf{4 . 6 4}$ \\
\hline
\end{tabular}

Source: Authors' own analysis. 
Finally, within the eighth field of competence (Tab. 9) - cooperation with colleagues the pre-primary educators are most ready to accept remarks, queries and advice from other teachers $(M=4.64)$. School teachers can cooperate in a variety of ways, for instance sharing information about children's linguistic abilities, observing each other's lessons, and providing useful feedback. A regular cooperation may turn out to be valuable, especially with regard to the way of handling language interactions in different everyday situations.

Table 9. Cooperation with colleagues

\begin{tabular}{|l|c|}
\hline \multicolumn{1}{|c|}{ VIII. Cooperation with colleagues } & Mean score \\
\hline 8.1. I can share my ideas and activities with other teachers & 4.57 \\
\hline $\begin{array}{l}\text { 8.2. I can collaborate with other team members on joint projects related } \\
\text { to the children's linguistic development }\end{array}$ & 4.51 \\
\hline $\begin{array}{l}\text { 8.3. I can accept remarks, queries and advice from colleagues or teacher } \\
\text { educators and take them into account in my management of the group }\end{array}$ & $\mathbf{4 . 6 4}$ \\
\hline $\begin{array}{l}\text { 8.4. I can provide colleagues with useful information about the linguistic } \\
\text { development of the children for whom I am responsible }\end{array}$ & 4.49 \\
\hline $\begin{array}{l}\text { 8.5. I can use the resources offered by partnerships with other institutions } \\
\text { or associations }\end{array}$ & 4.49 \\
\hline
\end{tabular}

Source: Authors' own analysis.

The questionnaire ended with the following open question: 'Would you suggest any changes to the curriculum or is there anything that you would like to add to the content of the programme?'. Less than a half of the course participants (42\%) responded to this question. The most common suggestions (45\%) pertained to the presentation of even more practical ideas for classroom work with young learners. Teachers highly appreciated all the workshops and expressed their satisfaction from taking part in them. Some teachers $(22 \%)$ also made comments with reference to Practical English. They would like to have conversations with a native speaker and more phonetics classes. Moreover, a few respondents $(10 \%)$ mentioned that more time should be devoted to the issue of coursebook selection for young and very young learners.

\section{Discussion}

In view of the aforementioned results the presupposition that teachers of very young learners can act as agents of ELP policy, which focuses on developing very young learners' interest in other languages and cultures seems to be justified. The Early Childhood Education teachers can be adequately prepared to this role through in-service training, such as the postgraduate course in question, in which the PEPELINO portfolio was one of the tools. The descriptors in the portfolio constitute a certain benchmark to be achieved via 
a training course. The overall findings show that the teachers in general benefited from the course as was indicated by a strong support for the majority of statements in seven categories (Tab. 1). The mean scores for all categories except one were above 4.0. The statements referred to pedagogical aspects of working with children at school as well as teaching a second language. First of all, the teachers knew how to work with colleagues and children's parents, but they also claimed that they 'understood how children learn' or 'responded to children's individual possibilities and needs'. These supportive beliefs might have resulted from the fact that the teachers already graduated from the Early Childhood Education Department and were accepted to the postgraduate programme on the basis of the certificate/exam showing language skills at the B2 level. Therefore, the participants were already willing and prepared to work with very young learners, not to mention, the short teaching experience they had. Additionally, they had sufficient knowledge of L2 (ca. at the B2 level), which allowed them to talk to children in L2 and also develop positive attitudes to linguistic and cultural diversity. This makes a good prognosis for the teachers to play the role of policy agents in promoting plurilingualism and intercultural interests of very young learners.

The only difficulty that was observed concerned 'Supporting the linguistic development of children with other first languages than Polish' $(M=3.87)$. This category of statements referred to the integration of children with migrant and multilingual backgrounds, of which the participants seemed to have little experience, either due to the overall teaching experience, or due to living in a largely homogenous society. Little is also known of the teacher participants' experience of living/studying abroad. This finding shows that despite having classes devoted to teaching children of various ethnolinguistic backgrounds, it is more difficult to find concrete solutions of how to work with such children. This finding is not so surprising, as similar difficulties can be also found among teachers who work in multilingual setting (cf. e.g. Christison et al. 2021). By the same token, the statement (2.5) referring to the ability to 'identify possible causes of misunderstanding due to differences of cultural behaviour and act as a mediator between children and adults'scored below 4 . $(\mathrm{M}=3.92)$. Acting as a cultural mediator appears to be a challenge for the trainees for the same reasons as above. This finding would be in accord to other research, in which participants' beliefs did not change after the completion of a teacher training programme (Karavas, Drossou 2010; Abasifar, Fotovatnia 2015), as "belief change during adulthood is a relatively rare phenomenon" (Pajares 1992: 325).

Additionally, it has to be recognized that the participants taking part in the study were not representative of the population of teachers. These were rather ambitious individuals who signed up to the course in order to gain additional qualifications. Besides they had no experience in language teaching. This is a serious limitation of the study. Yet, the data obtained signals difficulties which may be investigated further on a large scale. It could, for instance, be hypothesized and tested whether teachers' experience of living/studying abroad may facilitate the teachers' role of intercultural mediators as well as enhance awareness of language difficulties of children with migrant background. 


\section{Conclusion}

The PEPELINO is a portfolio aimed at pre-primary educators embarking on initial professional work and for those who already work with children and wish to improve their professional qualifications. It seeks to encourage consideration of educational policy issues related to the acquisition of language socialisation, the development of plurilingual competence, intercultural education and recognition of children's individual language repertoires when implementing curricula in different learning contexts (Goullier et al. 2015).

In the course of the study described, PEPELINO was used as a tool for personal reflection on professional teaching competences in a monolingual setting. The pre-primary educators of Polish origin who took part in the study benefited from the postgraduate studies and realised their fortes and flaws in the eight fields of competence - 40 descriptors altogether. In this respect, the use of the portfolio proved to be a valuable tool for early language learning policy and can, as such, be highly recommended.

\section{References}

Abasifar S., Fotovatnia Z. (2015), Impact of teacher training course on Iranian EFL teachers' beliefs. "International Journal of Foreign Language Teaching \& Research", 9(3).

Altman C., Goldstein T., Armon-Lotem S. (2018), Vocabulary, Metalinguistic Awareness and Language Dominance Among Bilingual Preschool Children. "Frontiers in Psychology", 23 October 2018, https://doi.org/10.3389/fpsyg.2018.01953, 15.09.2020.

Bialystok E., Peets K.F., Moreno S. (2014), Producing bilinguals through immersion education: Development of metalinguistic awareness. "Applied. Psycholinguistics", 35.

Bustos Flores B. (2001), Bilingual Education Teachers' Beliefs and Their Relation to Self-Reported Practices. "Bilingual Research Journal", 25. DOI: 10.1080/15235882.2001.10162795.

Byram M. (1997), Teaching and Assessing Intercultural Communicative Competence. Clevedon, Multilingual Matters.

Christison M.A., Krulatz A., Sevinç Y. (2021), Working with Teachers and Young learners in Multilingual Classrooms: Introducing the Multilingual Approach to Diversity in Education (MADE). In: J. Rokita-Jaśkow, A. Wolanin (eds.), Facing diversity in child foreign language education. Cham, Springer.

Council of Europe (2001), The Common European framework of reference for languages: Learning, teaching and assessment. Cambridge: Cambridge University Press. http://www.coe.int/t/dgg/ linguistic/source/manual/revision-proofread-final_en.pdf, 2.08.2021.

Cregan A. (2019), Promoting Oral Language Development in the Primary School. Dublin, The National Council for Curriculum and Assessment (NCCA).

De Angelis G. (2011), Teachers' beliefs about the role of prior language knowledge in learning and how these influence teaching practices. "International Journal of Multilingualism", 8. DOI: 10.1080/14790718.2011.560669.

Enever J. (2018), Policy and Politics in Global Primary English. Oxford, Oxford University Press. 
European Commission (1995), White Paper: Teaching and Learning-Towards the Learning Society. https://op.europa.eu/en/publication-detail/-/publication/d0a8aa7a-5311-4eee-904c-98fa541108 d8/language-en, 15.09.2020.

European Commission (2011a), Early Language Learning at Pre-Primary Level in Europe: Current Situation and Future Perspectives. http://ec.europa.eu/dgs/education_culture/repository/ languages/policy/language-policy/documents/ellphb-summaries_en.pdf, 12.07.2017.

European Commission (2011b), Language learning at pre-primary school level: making it efficient and sustainable. Policy Handbook. http://ec.europa.eu/dgs/education_culture/repository/languages/ policy/language-policy/documents/early-language-learning-handbook_en.pdf, 12.07.2017.

European Commission (2017), Key Data on Teaching Languages at school in Europe. https://eacea. ec.europa.eu/national-policies/eurydice/content/key-data-teaching-languages-school-europe$\%$ E2\%80\%93-2017-edition_en, 15.09.2020.

Fojkar D.M., Skubic D. (2017), Pre-Service Preschool Teachers' Beliefs about Foreign Language Learning and Early Foreign Language Teaching in Slovenia. "CEPS Journal”, 7.

Goullier F., Carré-Karlinger C., Orlova N., Roussi M. (2015), European language portfolio for preprimary educators. The plurilingual and intercultural dimension. European Centre for Modern Languages, Council of Europe, https://www.ecml.at/Portals/1/mtp4/pepelino/pepelino-EN-web. pdf, 15.09.2020.

Haukås Å. (2016), Teachers' beliefs about multilingualism and a multilingual pedagogical approach. "International Journal of Multilingualism", 13. DOI: 10.1080/14790718.2015.1041960.

Karavas E., Drossou M. (2010), How amenable are student teacher beliefs to change? A study of EFL student teacher beliefs before and after teaching practice. In: A. Psaltou-Joycey, M. Matheoudakis (eds.), Advances in Research on Language Acquisition and Teaching: Selected Papers. Thessaloniki, Greek Applied Linguistic Association.

Kirsch C. (2018), Dynamic interplay of language policies, beliefs and pedagogy in a preschool in Luxembourg. "Language and Education", 32. DOI: 10.1080/09500782.2018.1487452.

Lundberg A. (2019), Teachers' beliefs about multilingualism: findings from $Q$ method research. “Current Issues in Language Planning”, 20. DOI: 10.1080/14664208.2018.1495373.

Ministry of Polish Education (2014), Regulation on the Core Curriculum for Kindergarten and general Education. Dziennik Ustaw [Journal of Laws] z 2014 r., poz. 803. http://isap.sejm.gov. pl/DetailsServlet?id=WDU20140000803, 12.10.2020.

Ministry of Polish Education (2017), Regulationon the New Core Curriculum for Kindergarten and General Education in Primary school. Dziennik Ustaw [Journal of Laws] z 2017 r., poz. 356. http://www.dziennikustaw.gov.pl/DU/2017/356, 12.10.2020.

Murphy V., Evangelou M. (eds.) (2016), Early Childhood education in English for Speakers of Other Languages. London, British Council.

Newby D., Allan R., Fenner A-B., Jones B., Komorowska H., Soghikyan K. (2007), The European Portfolio for Student-Teachers of Languages. Graz, ECML.

Otwinowska A. (2017), English teachers' language awareness: Away with the monolingual bias? "Language Awareness", 26(4).

Pajares M.F. (1992), Teachers' beliefs and educational research: Cleaning up a messy construct. "Review of Educational Research", 62(3).

Portolés L., Martí O. (2018), Teachers' beliefs about multilingual pedagogies and the role of initial training. "International Journal of Multilingualism", 17(2). 
Rokita-Jaśkow J. (2016), Kindergarten teachers' beliefs about the goals of very early FL instruction and their classroom practices: is there a link? In: M. Pawlak (ed.), Classroom-Oriented Research, Second Language Learning and Teaching, Heidelberg-New York, Springer. DOI 10.1007/978-3-319-30373-4.

Rokita-Jaśkow J., Pamuła-Behrens M. (2019), Policy and practice in early FLL: the case of Poland. In: J. Rokita-Jaśkow, M. Ellis. (eds.), Early instructed SLA: Pathways to competence. Bristol, Multilingual Matters. 